\title{
Raz jeszcze o odpowiedzialności za przywłaszczenie przedmiotu wchodzącego do majątku wspólnego małżonków
}

\begin{abstract}
The legal assessment of misappropriation of property belonging to community property by one of the spouses constitutes a heavily contested issue in criminal law. The article analyzes a well-established opinion, according to which such property can be the object of the crime of misappropriation, and which cites the rules of the civil law. The article focuses on the issue of the possibility of assuming in such cases an attack on property, i.e. a violation of the object of the offence, discussed from the perspective of family law, which allows spouses to dispose of such property without the permission of the other spouse, on the basis of the rule of independent property management. Moreover, the author verifies the prerequisite for the seizure of third-party property, given that the property in question belongs also to the defendant, in accordance with the rules of community property. In addition to that, the author discusses the issue of meeting the prerequisites for the subjective aspect and the rule for evaluating the damage inflicted by the offence. The latter issue has been identified as particularly controversial, given that determining the scope of the possible restitution claims according to the value of property which constitutes the object of the offence in a situation where the property belongs also to the defendant is contrary to the intuition of criminal law scholars.
\end{abstract}

Key words: misappropriation of property belonging to the spouses' community property, misappropriation, theft

W doktrynie i judykaturze spory dotyczące karnoprawnej oceny przywłaszczenia przedmiotu wchodzącego do majątku wspólnego małżonków, dokonanego przez jednego z nich, toczące się ze szczególnym natężeniem w latach pięćdziesiątych i sześćdziesiątych ubiegłego stulecia, w ostatnim czasie wyraźnie przycichły. Ugruntował się dość powszechnie pogląd, według którego mienie takie co do zasady może stanowić przed- 
miot przestępstwa przywłaszczenia, gdyż rzecz jest dla sprawcy częściowo cudza, nie jest on więc jej wyłącznym dysponentem, co zobowiązuje go do współdziałania z małżonkiem w zarządzie rzeczą wspólną. Zaś przyjęcie wypełnienia znamion kradzieży w takiej sytuacji nie jest uzasadnione, skoro sprawcy - jako współwłaścicielowi - przysługuje władztwo nad składnikami wchodzącymi w skład majątku wspólnego. Nie jest możliwe tym samym uznanie, że dokonuje on zaboru rzeczy spod władztwa osoby uprawnionej, a raczej, że jedynie uniemożliwia korzystanie $\mathrm{z}$ takiego przedmiotu ${ }^{1}$.

Wskazane powyżej stanowisko zostało obudowane bogatymi poglądami doktryny i judykatury, pochodzącymi w szczególności z ostatniego stulecia. Z czasem wątpliwości zaczęły cichnąć, pytanie tylko, czy zasadnie, a to wobec kolejnych zmian dokonywanych na gruncie prawa rodzinnego, w zakresie zasad zarządu majątkiem wspólnym. W istocie chodzi o nowelizację Kodeksu rodzinnego i opiekuńczego, która weszła w życie z dniem 20 stycznia 2005 r. $^{2}$. Zakładała ona zniesienie pojęcia czynności zwykłego zarządu i czynności przekraczających zakres zwykłego zarządu, z jednoczesnym enumeratywnym wymienieniem czynności wymagających zgody drugiego małżonka ${ }^{3}$. Obecnie każdemu z małżonków przysługuje prawo do samodzielnego zarządu majątkiem wspólnym, co jednak nie zwalnia żadnego z nich z obowiązku współdziałania w tym zakresie ${ }^{4}$. Pytanie, czy przyznanie tak szerokich uprawnień w zakresie dysponowania rzeczami wspólnymi nie przesądziło o dekryminalizacji przestępstwa przywłaszczenia pomiędzy małżonkami co do przedmiotów pozostających w majątku wspólnym.

Opisana powyżej nowelizacja dość szybko wzbudziła w sądach karnych wątpliwości co do zasadności dalszego stosowania utrwalonej linii judykatury. Sąd Okręgowy w K., rozpoznając apelację wniesioną przez prokuratora od wyroku Sądu Rejonowego w D., którym uniewinniono oskarżonego od zarzutu popełnienia przestępstwa określonego w art. 284 $\S 2$ k.k., polegającym na przywłaszczeniu powierzonego mu mienia w postaci samochodu osobowego marki Fiat 126p, stanowiącego część majątku małżeńskiego, uznał, że w sprawie wyłoniło się zagadnienie prawne

1 Tak: R.A. STEFAŃSKI: Odpowiedzialność karna za zabór mienia stanowiacego wspólność majątkowa. Prok. i Pr. 1995, nr 10, s. 117 i nast.; wyrok SN z dnia 14 listopada 1972 r., V KRN 421/72, OSNKW 1973/5/61; A. SoŚNICKA: Przestępstwo i wykroczenie przywtaszczenia w polskim prawie karnym. Warszawa 2013, s. 1752-173; M. DĄBRowsKA-Kardas, P. Kardas. W: Kodeks karny. Część szczególna. T. III: Komentarz do art. 278-363. Red. A. Zoll. Warszawa 2016, s. 229-230.

${ }^{2}$ Ustawa z dnia 17 czerwca 2004 r., Dz.U. 2004, nr 162, poz. 1691.

3 Tak: K. Pietrzyкowsкi. W: Kodeks rodzinny i opiekuńczy. Komentarz. Red. K. PIETRZYKowsKi. Warszawa 2015, s. 295.

${ }^{4}$ J. Ignaczewski: Kodeks rodzinny i opiekuńczy. Komentarz. Warszawa 2010, s. 181. 
wymagające zasadniczej wykładni ustawy. Sąd powziął wątpliwości, czy nowelizacja z dnia 17 czerwca 2004 r. k.r.o., która weszła w życie dnia 20 stycznia 2005 r., zmieniła w odniesieniu do mienia ruchomego, stanowiącego majątek wspólny, oceny karnoprawnego przywłaszczenia, przerzucając skutki takich zachowań do rozliczeń majątkowych wywołanych różną sytuacją prawną.

Sąd Najwyższy, rozpoznając przedstawioną mu powyżej sprawę, w postanowieniu z dnia 29 sierpnia 2007 r. $^{5}$ stanął na stanowisku, że zmienione ustawą z dnia 17 czerwca 2004 r. ${ }^{6}$ przepisy Kodeksu rodzinnego i opiekuńczego, wprowadzające nowy model zarządzania majątkiem wspólnym i zmodyfikowane instrumenty cywilnoprawnej ochrony interesów małżonków, nie wprowadzają zmian, które miałyby znaczenie dla odpowiedzialności karnej małżonka dopuszczającego się czynów dysponowania majątkiem wspólnym z zamiarem powiększenia swego majątku kosztem majątku drugiego małżonka. Podkreślił on, że w prawie karnym zasadą jest, iż nie jest działaniem przestępnym zachowanie się osoby, która wypełnia wprawdzie znamiona przestępstwa, jednakże czyni to $\mathrm{w}$ ramach przysługujących jej uprawnień, wynikających na ogół z przepisów należących do innych dziedzin prawa. Działanie w ramach uprawnień jest ogólną okolicznością wyłączającą odpowiedzialność karną, opierającą się na założeniu braku sprzeczności wewnątrz danego systemu prawa. Jeżeli jakaś dziedzina prawa daje komuś prawo do zachowania się w określony sposób, to czyn taki nie może być podstawą do pociągnięcia tej osoby do odpowiedzialności karnej, mimo że wypełnia znamiona czynu zabronionego przez ustawę karną.

W dalszej części przywoływanego uzasadnienia zauważono, że nowe uregulowania dotyczące ustawowego ustroju majątkowego dokonują szeregu zmian w składzie majątku wspólnego, a zwłaszcza w zakresie zarządu tym majątkiem, które były konieczne ze względu na przyjęcie w Polsce modelu społecznej gospodarki rynkowej. Nie wprowadzają jednak żadnych zmian, które miałyby znaczenie dla odpowiedzialności karnej małżonka dopuszczającego się czynów dysponowania majątkiem wspólnym z zamiarem powiększenia swego majątku kosztem majątku drugiego małżonka ${ }^{7}$. Sąd Najwyższy nie przedstawił jednak powodów, dla których $\mathrm{w}$ jego ocenie wskazana zmiana ustawy nie wywiera wpływu na karnoprawną ocenę zachowania małżonka przywłaszczającego mienie wchodzące w skład majątku wspólnego.

${ }^{5}$ I KZP 18/07, OSNKW 2007/9/64.

${ }^{6}$ Dz.U. nr 162, poz. 1691.

7 Tak: I KZP 18/07, OSNKW 2007/9/64. 
Ponaddziesięcioletni okres, który minął od przekształcenia zasad zarządu majątkiem wspólnym małżonków, skłania do refleksji nad zasadnością przyjętego przez Sąd Najwyższy stanowiska i utrwalonej w oparciu o powyższy judykat praktyki orzeczniczej, zwłaszcza że nieprzedstawienie pogłębionych argumentów przemawiających za wybranym przez SN poglądem utrudnia weryfikację wyciągniętych ostatecznie wniosków.

Rozważając zasadność zaprezentowanego powyżej stanowiska, należy w pierwszej kolejności zastanowić się, czy rzeczywiście zmiana przepisów regulujących zasady zarządem majątkiem wspólnym małżonków nie zmieniła karnoprawnej oceny zachowania małżonka przywłaszczającego sobie rzecz należącą do majątku wspólnego. W istocie rezygnacja z podziału na czynności zwykłego zarządu i czynności przekraczające zwykły zarząd na rzecz zasady samodzielnego decydowania o majątku wspólnym prowadzić może do przyjęcia stanowiska przeciwnego. Skoro obecnie każdy z małżonków ma legitymację (z wyjątkami określonymi w przepisach) do swobodnego zarządzania majątkiem, przykładowo poprzez podjęcie decyzji o sprzedaży rzeczy, to przyznanie takiego uprawnienia przez dziedzinę prawa regulującą określony stosunek prawny wyłącza możliwość przyjęcia $\mathrm{w}$ takiej sytuacji popełnienia przestępstwa przywłaszczenia, z uwagi na zasadę subsydiarności prawa karnego i potrzebę harmonizacji przepisów $^{8}$. Chodzi o to, że skoro $\mathrm{w}$ myśl przepisów prawa rodzinnego małżonek może samodzielnie sprzedać na przykład samochód należący do majątku wspólnego, postępując z tym przedmiotem jak właściciel, to nie można pociaggać go z tego tytułu do odpowiedzialności karnej. Problemu tego nie da się rozstrzygnąć bez analizy pojęcia zarządu majątkiem wspólnym i skorelowanych z tą kategorią uprawnień i obowiązków ciążących na małżonkach.

W nauce prawa rodzinnego podkreśla się, że samodzielny zarząd majątkiem wspólnym polega, w myśl art. 36 § zd. pierwsze k.r.o., na prawie każdego z małżonków do samodzielnego dokonywania czynności zarządu, co przejawia się działaniem we własnym imieniu, choć skutki dokonanych czynności wystąpią w sferze wspólnego interesu obojga małżonków ${ }^{9}$. Wyjątki od tej zasady muszą zostać wyraźnie uregulowane. Wadliwe zarządzanie majątkiem wspólnym w stosunkach między małżonkami może prowadzić do pozbawienia małżonka możliwości samodzielnego wykonywania zarządu (art. 40 k.r.o.) lub - w skrajnym przypadku - do ustanowienia przez sąd rozdzielności majątkowej (art. 52 § 1

${ }^{8}$ Zob. O. GóRnIoK: Znaczenie subsydiarności prawa karnego $w$ jego interpretacji. PiP 2007, nr 5, s. 49 i nast.; S. ŻółteK: Prawo karne gospodarcze w aspekcie zasady subsydiarności. Warszawa 2009, s. 168 i nast.

9 A. Sylwestrzak. W: Zarzq̨d majątkiem wspólnym. Komentarz. Red. M. Balwicka-SzCZYRBA. Warszawa 2016, s. 290. 
k.r.o.), nie odnosi natomiast, poza sytuacjami wymienionymi w art. 37 § 1 k.r.o., skutków w stosunku do osób trzecich, dokonujących czynności $\mathrm{z}$ jednym z małżonków ${ }^{10}$. Oznacza to, że małżonek pokrzywdzony na przykład sprzedażą samochodu nie może skutecznie zakwestionować zakupu pojazdu przez osobę trzecią. Wadliwe wykonywanie zarządu może również wywierać wpływ na modyfikację wielkości udziałów w majątku wspólnym po ustaniu wspólności (art. 43 § 2 k.r.o.), a wreszcie zawinione przez jedno z małżonków naruszenie obowiązku współdziałania w zarządzie majątkiem wspólnym może powodować odpowiedzialność odszkodowawczą względem współmałżonka (art. 415 k.c.) $)^{11}$.

Obowiązywanie zasady samodzielnego wykonywania zarządu majątkiem wspólnym uzupełnia obowiązek informacyjny, polegający na konieczności wzajemnego udzielania informacji o stanie majątku, o zobowiązaniach obciążających majątek oraz o dokonywanych czynnościach zarządu, jako że małżonek niewykonujący zarządu powinien mieć orientację w zakresie czynności dokonywanych przez współmałżonka ${ }^{12}$. Z regułą tą koreluje utrwalony pogląd, że obowiązek współdziałania w zarządzie dotyczy tylko stosunków wewnętrznych między małżonkami ${ }^{13}$. Wobec tego konieczność wzajemnego informowania się małżonków nie koliduje z zasadą samodzielnego wykonywania zarządu, której obowiązywanie rozstrzyga o skuteczności czynności dokonanych samodzielnie niezależnie od tego, czy pomiędzy małżonkami miało miejsce prawidłowe współdziałanie ${ }^{14}$.

Ustalając, że małżonkom przysługuje prawo do samodzielnego zarządu przedmiotami należącymi do wspólności ustawowej małżeńskiej, należy zastanowić się nad kryteriami oceny pozwalającymi na przyjęcie, że określone zachowanie małżonka może zostać uznane za wykonywanie takiego zarządu, innymi słowy, że wchodzi w zakres tego pojęcia. Nie budzi większych sporów, że zarząd majątkiem wspólnym obejmuje czynności, które dotyczą, wiążą się z majątkiem wspólnym ${ }^{15}$, sporne jest natomiast ustalenie klasyfikacji czynności, które mogłyby zostać uznane za

${ }^{10}$ E. SKowrońsKa-Bocian. W: Kodeks rodzinny i opiekuńczy. Komentarz. Red. J. Wierciński. Warszawa 2014, s. 361. Por. też: T. SokoŁowski. W: Kodeks rodzinny i opiekuńczy. Red. H. Dolecki, T. SokoŁowsкi. Warszawa 2013, s. 190.

11 M. Sychowicz. W: Kodeks rodzinny i opiekuńczy. Komentarz. Red. K. Piasecki. Warszawa 2011, s. 237.

12 Е. SKowrońsKa-Bocian. W: Kodeks rodzinny..., s. 361.

13 Tak: T. Mróz: Zgoda małżonka na dokonanie czynności prawnej w ustroju majątkowej wspólności ustawowej. Warszawa 2011, s. 92; A. SylwestrzaK. W: Zarzad..., s. 300.

14 A. SylwestrzaK. W: Zarząd..., s. 300.

15 S.K. Rzonca: Pojęcie zarzq̨du majątkiem wspólnym matżonków. Warszawa 1982, s. 21; M. Sychowicz. W: Kodeks rodzinny..., s. 234; A. SylwestrzaK. W: Zarząd..., s. 273. 
dotyczące majątku wspólnego ${ }^{16}$. O zaliczeniu danej czynności do zarządu majątkiem wspólnym w opinii części przedstawicieli doktryny decyduje związek funkcjonalny lub inny zamierzony przez strony, wskazujący na cel czynności jako dotyczącej przedmiotu majątkowego wchodzącego w skład majątku wspólnego ${ }^{17}$; w opinii innych o powyższym powinna decydować treść stosunku prawnego i jej efekt gospodarczy ${ }^{18}$. Przyjmując tak luźne definicje zarządu majątkiem wspólnym, należałoby uznać, że sprzedaż pojazdu mechanicznego osobie trzeciej wchodzi w zakres tego pojęcia, nawet jeżeli celem tej czynności było zwiększenie majątku jednego małżonka kosztem drugiego, a tym samym, wobec umocowania do takiego zachowania w prawie rodzinnym, brak jest podstaw do objęcia kryminalizacją wskazanej czynności prawnej.

Wielu przedstawicieli doktryny stoi jednak na stanowisku, że dla uznania określonej czynności za zarząd majątkiem wspólnym nie jest wystarczające, by ta w bezpośredni sposób odnosiła się do przedmiotów wchodzących w skład majątku wspólnego. W konsekwencji poszukiwano elementów ograniczających zakres tej definicji. Wskazano między innymi, że w zarządzie zwykle chodzi o działania w sferze prawnej innej osoby, w cudzym interesie bądź interesie własnym zarządcy i osoby przez niego reprezentowanej ${ }^{19}$. Prowadziło to do konkluzji, że o czynnościach dotyczących zarządu majątkiem wspólnym można mówić wyłącznie w sytuacji, gdy jest ona dokonywana wobec osób trzecich ${ }^{20}$. K. Gołębiowski zaznaczył, że zarząd majątkiem wspólnym polega na podejmowaniu przez małżonków w stosunku do osób trzecich działań, których skuteczność jest uzależniona przez normy prawne od przysługiwania podmiotowi działającemu uprawnień, wchodzących w danej sytuacji w skład majątku wspólnego, nie obejmuje natomiast działań dokonywanych między samymi małżonkami, nawet jeżeli ich skuteczność zależy od przysługiwania wspólnych praw ${ }^{21}$.

Koncepcja ta zasługuje na uznanie, ponieważ zasady zarządu majątkiem wspólnym rzeczywiście regulować mają stosunki majątkowe małżonków z osobami trzecimi, pozwalając działać tylko jednemu z nich, ze skutkami dla małżonka niewykonującego zarządu. Zaaprobowanie

16 K. GoŁęвIOwsкI: Zarzq̨d majątkiem wspólnym matżonków. Warszawa 2012, s. 151-152.

17 M. Sychowicz: Uwagi o zakresie zarzq̨u majątkiem wspólnym matżonków. W: Księga jubileuszowa Profesora Tadeusza Smyczyńskiego. Red. A. ANDRzejewsKi, L. KociUcKi, M. ŁączKowsKa, A.N. Schulz. Toruń 2008, s. 269.

18 S.K. Rzonca: Pojęcie zarządu..., s. 24-25.

19 Ibidem, s. 11.

20 Tak: K. GoŁĘBIowski: Zarząd majątkiem..., s. 280-281. Zob. uwagi do powyższego stanowiska: A. SylweSTRZAK. W: Zarzad majątkiem..., s. 275.

${ }^{21}$ K. GoŁęBIOwsKi: Zarząd majątkiem..., s. 280-281. 
tego poglądu pozwala również harmonijnie wytłumaczyć przyczyny, dla których regulacje prawa rodzinnego nie uchylają bezprawności działania sprawcy przywłaszczającego sobie przedmioty należące do majątku wspólnego. Jeżeli sprawca chce samowolnie sprzedać samochód należący do majątku wspólnego osobie trzeciej, to przepisy prawa rodzinnego mu na to pozwalają, a wskazana umowa będzie ważna i skuteczna wobec kontrahenta. Działanie to nie będzie jednak legalne wobec współmałżonka, ponieważ zasady samodzielnego zarządu regulują stosunki majątkowe „ze światem zewnętrznym”, a nie pomiędzy samymi małżonkami. Z tego też względu nie jest dozwolone samodzielne, bez wiedzy współmałżonka, przenoszenie do majątku osobistego przedmiotów o większej wartości $\mathrm{w}$ celu powiększenia swojego majątku osobistego ${ }^{22}$. Takie zachowania nie są również aprobowane w prawie rodzinnym. Jakkolwiek w dawniejszym orzecznictwie wskazywano na możliwość żądania rozliczenia z tytułu nieuzasadnionego zbycia i roztrwonienia przez drugiego małżonka składników majątku wspólnego na podstawie art. 415 k.c. ${ }^{23}$, obecnie, z uwagi na trudności w przypisaniu małżonkowi dokonującemu czynności bezprawności, w szerszej mierze sądy decydują się na stosowanie w drodze analogii art. 45 k.r.o. ${ }^{24}$, z zobowiązaniem do zapłaty na rzecz współmałżonka części wartości odpowiadającej jego udziałowi w majątku wspólnym ${ }^{25}$. $\mathrm{Z}$ tego też względu należy stanąć na stanowisku, że skoro odpowiedzialność za zabór mienia wchodzącego w skład wspólności majątkowej małżeńskiej dotyczy stosunków pomiędzy małżonkami, a nie relacji z osobami trzecimi, prawo samodzielnego zarządu majątkiem wspólnym nie stoi na przeszkodzie kryminalizacji zachowań polegających na przywłaszczeniu rzeczy znajdującej się $\mathrm{w}$ przedmiotowej masie majątkowej. Tym samym odpowiedzialności za przywłaszczenie rzeczy z majątku wspólnego nie sprzeciwia się prawo małżonków do samodzielnego zarządu.

W dalszej kolejności należy rozważyć, czy przeszkodą w przyjęciu takiego rozwiązania nie jest prawo własności współmałżonków względem rzeczy stanowiącej przedmiot czynności wykonawczej ewentualnego przestępstwa przywłaszczenia. W judykaturze silnie ugruntowało się stanowisko, według którego takie mienie, jakkolwiek częściowo własne, jest również częściowo cudze, jako należące do drugiego małżonka, a więc do innej osoby ${ }^{26}$. U podstaw przyjęcia przez karnistów powyższego stano-

22 T. SoкоŁowski. W: Kodeks rodzinny..., s. 190.

23 Postanowienie SN z dnia 17 kwietnia 2000 r., V CKN 25/00, LEX nr 1129169.

${ }^{24}$ Uchwała SN z dnia 15 września 2004 r., III CZP 46/04, OSNC 2005/9/152; postanowienie SN z dnia 12 maja 2016 r., IV CSK 600/15, Legalis nr 1488828.

${ }_{25}$ Por. postanowienie SN z dnia 13 marca 1981 r., III CRN 35/81, OSNC 1981/11/220.

${ }^{26}$ Por. wyrok SA w Warszawie z dnia 30 października 2013 r., II AKa 322/13, LEX nr 1392064; wyrok SA w Katowicach z dnia 30 kwietnia 2015 r., II AKa 62/15, LEX nr 1745770. 
wiska legła teza, że sprawca nie dysponuje wówczas wyłącznym prawem własności przysługującym mu względem rzeczy ${ }^{27}$. Art. $34^{1}$ k.r.o. dekretuje dla każdego z małżonków uprawnienie do współposiadania rzeczy wchodzących w skład majątku wspólnego oraz do korzystania $\mathrm{z}$ nich w takim zakresie, jaki daje się pogodzić ze współposiadaniem i korzystaniem z rzeczy przez drugiego małżonka. Tym samym ustawodawca zapewnił każdemu z małżonków uprawnienie do posiadania i korzystania z rzeczy, a godzenie w tę sferę narusza cudze prawo własności.

Nie wszyscy przedstawiciele doktryny zgodzili się z zarysowanym powyżej stanowiskiem. Wśród przeciwników tego poglądu formowały się dwie główne linie argumentacji. W opinii J.F. Marca charakteryzujący wspólność ustawową brak oznaczonego udziału i przysługiwanie jednakowych praw do majątku wspólnego nie pozwalają na przyjęcie, że w okresie trwania wspólności majątkowej rzecz taka jest dla sprawcy cudza, skoro dopiero z chwilą ustania wspólności prawo do całości majątku zostanie zastąpione określonym ułamkowo udziałem ${ }^{28}$. Pogląd ten wydaje się jednak nietrafny o tyle, że nieoznaczenie udziałem prawa do majątku wspólnego nie zmienia faktu, iż znajdujące się tam przedmioty nie należą w całości do jednego małżonka, a przydanie możliwości samodzielnego zarządzania majątkiem $z$ osobami trzecimi nie zmienia oceny prawnej zachowania sprawcy zmierzającego do pozbawienia współmałżonka przysługującego mu prawa własności względem rzeczy.

$\mathrm{Na}$ innego rodzaju argumentację powoływała się M. Gałązka, wskazująca na treść art. 195 k.c., z której można wyciągnąć wniosek, że rzecz wspólna jest dla współuprawnionego rzeczą własną z tym zastrzeżeniem, że jest ona własnością także innej osoby, dlatego współwłaścicielowi nie można przypisać celu przywłaszczenia rzeczy, lecz przywłaszczenie prawa majątkowego ${ }^{29}$. W doktrynie poddano ten pogląd krytyce, jako przywiązujący zbytnią uwagę do regulacji cywilnoprawnych, skoro, od strony skutków, pozbawienie jednego współwłaściciela władztwa nad rzeczą przez innego współwłaściciela nie różni się niczym od tego, gdy tego władztwa miałaby go pobawić osoba trzecia ${ }^{30}$. Przywołane uwagi krytyczne są trafne o tyle, że prawo karne, zwłaszcza w zakresie przestępstw przeciwko mieniu, tradycyjnie przydaje przedmiotom czynności wykonawczej od-

27 Por. A. SośnicKa: Przestępstwo i wykroczenie przywtaszczenia $w$ polskim prawie karnym. Warszawa 2013, s. 170-173.

${ }_{28}$ J.F. MARzEC: Z problematyki zaboru przez jednego z matżonków mienia objętego wspólnościq ustawowa. PiP 1959, nr 11, s. 848, 850.

${ }_{29}$ M. GatązKa: Przywtaszczenie na szkodę wspótwłaściciela $w$ świetle polskiego prawa karnego. PiP 2013, nr 11, s. 75 i nast.

30 M. DudzIK: Glosa do postanowienia Sądu Najwyższego z dnia 28 marca 2012 r., I KZP 1/12. „Ius Novum” 2013, nr 3, s. 279. 
mienne desygnaty aniżeli ma to miejsce $\mathrm{w}$ prawie cywilnym ${ }^{31}$, a próba usilnego nakładania cywilistycznej siatki pojęciowej na instytucje prawa karnego musi skończyć się niepowodzeniem.

Z przywołanych powyżej względów należy zaakceptować stanowisko, zgodnie z którym przedmioty znajdujące się w majątku wspólnym są dla współmałżonków cudze. Nie można natomiast zgodzić się ze wszystkimi argumentami, które służyć miały potwierdzeniu tego stanowiska. W szczególności trudno zgodzić się z M. Dudzikiem, który na poparcie zarysowanej powyżej tezy odwołał się do art. 199 zd. pierwsze k.c., w myśl którego do rozporządzania rzeczą wspólną potrzebna jest zgoda wszystkich współwłaścicieli. Doprowadziło go to do przekonania, z powołaniem się na J. Satko, że pozycja sprawcy, który jest współwłaścicielem, nie różni się znacząco od sprawcy, który nie jest współwłaścicielem i tym samym nie ma prawa w ogóle rzeczą rozporządzać, co posłużyło do wyciągnięcia wniosku, że rzecz będąca przedmiotem współwłasności jest w tym kontekście rzeczą „cudzą” dla jej współwłaściciela ${ }^{32}$. Problem jednak w tym, że odwoływanie się w przypadku małżonków do regulacji współwłasności ułamkowej nie wydaje się trafne. $\mathrm{O}$ ile $\mathrm{w}$ przywołanym przypadku opisanej powyżej rzeczy wiadomo, że należy ona do różnych osób w określonych proporcjach i na określonych zasadach zarządu, to w przypadku współwłasności łącznej rzecz należy razem do małżonków, z prawem do samodzielnego zarządu nią i brakiem możliwości zobowiązania się do rozporządzenia udziałem, który przypadnie mu w razie ustania wspólności ustawowej ${ }^{33}$. Wspólność majątku nie ma w tym przypadku charakteru samodzielnego, uzależniając swoje istnienie od stosunku podstawowego, tj. małżeństwa, z jednoczesnym niewyłączeniem ustroju wspólności majątkowej przez przepisy bądź umowę zawartą przez strony ${ }^{34}$. W konsekwencji rację ma L. Kubicki, podnosząc, że wspólność małżeńska łączy się z większymi ograniczeniami aniżeli ułamkowa, ze względu na brak uprawnienia do rozporządzania swoim udziałem ${ }^{35}$. Trafny wydaje się

31 W prawie karnym jako przykład podawano niemożność uznawania np. lusterek w samochodzie za części składowe pojazdu, gdyż te, w myśl prawa cywilnego, nie mogą stanowić odrębnego przedmiotu własności od rzeczy głównej, z pewnością natomiast mogą stanowić przedmiot kradzieży. Por. M. DąbrowsKa-Kardas, P. Kardas. W: Kodeks karny..., s. 199 i nast.

32 M. DudziK: Glosa..., s. 279.

33 Jest to konsekwencja ukształtowania wspólności ustawowej jako bezudziałowej wspólności łącznej. Związany jest z nią zakaz podziału majątku wspólnego w czasie trwania wspólności ustawowej oraz zakaz rozporządzania udziałem w majątku wspólnym. Zob. szerzej: K. PIETRZYKowsKI. W: Kodeks rodzinny..., s. 290-291.

${ }^{34}$ Zob. J. IgNaCZEWsKr: Kodeks rodzinny..., s. 175 i nast.

${ }^{35}$ Zob. polemikę L. Kubickiego z J.F. Marcem na łamach „Państwa i Prawa” 1959, nr 11, s. 856. 
więc ostatecznie pogląd, że rzecz stanowiąca przedmiot czynności wykonawczej przestępstwa przywłaszczenia jest dla sprawcy cudza, albowiem nie stanowi jego wyłącznej własności, skoro współmałżonek nie może w tym okresie rozporządzić przydanymi mu prawami.

Kolejnym elementem niezbędnym do ustalenia możliwości przypisania małżonkowi przestępstwa przywłaszczenia rzeczy z majątku wspólnego jest poczynienie ustaleń z zakresu strony podmiotowej. Dla pociągnięcia do odpowiedzialności karnej należy bowiem stwierdzić, że sprawca rozporządzający samowolnie przedmiotami należącymi do majątku wspólnego miał zamiar powiększenia swojego osobistego majątku lub majątku osób trzecich kosztem współmałżonka ${ }^{36}$ tak, aby dana rzecz nie mogła być przedmiotem podziału majątku wspólnego ${ }^{37}$. Działanie małżonka nie ma charakteru przestępnego, nawet jeżeli działa on bez wymaganej zgody albo wręcz wbrew woli drugiego z małżonków, ale nie ma zamiaru powiększenia swego majątku kosztem jego (tj. drugiego z małżonków) majątku $^{38}$. Dla przypisania przestępstwa przywłaszczenia sprawca powinien mieć świadomość braku tytułu prawnego do dokonania takiego rozporządzenia, a w przypadku wspólności majątkowej małżeńskiej i zasady samodzielnego zarządu majątkiem wiedza o niemożności powiększenia własnego majątku kosztem majątku współmałżonka nie jest rzeczą oczywistą. W judykaturze podkreślano, że zbycie składników majątku wspólnego, a także późniejsze dowolne dysponowanie środkami w zamian uzyskanymi i wydawanie ich bez żadnej kontroli, jak gdyby ktoś był osobą wyłącznie uprawnioną do rozporządzania nimi, pozwala na przypisanie przestępstwa przywłaszczenia, skoro podział majątku wspólnego jest ustalany dopiero na moment ustania wspólności ${ }^{39}$. W istocie chodzić więc powinno o zabiegi sprawcy zmierzające do wyprowadzenia, bez wiedzy lub zgody drugiego małżonka, przedmiotów z majątku wspólnego. Nie ma przy tym znaczenia, czy rzecz taką następnie sprawca sprzedał i uzyskane ze sprzedaży pieniądze wykorzystał wyłącznie na swoje potrzeby, czy też darował ją osobie trzeciej lub wyrzuci ${ }^{40}$. Dla bytu przestępstwa przywłaszczenia istotny jest jedynie cel przywłaszczenia, przejawiający się $\mathrm{w}$ chęci postąpienia $\mathrm{z}$ rzeczą jak właściciel (w tym przypadku jedy-

${ }^{36}$ M. Dąbrowska-Kardas, P. Kardas: Nowa kodyfikacja karna. Kodeks karny. Przestępstwa przeciwko mieniu. Warszawa 1998, z. 21, s. 160; zob. też wyrok SN z dnia 24 listopada 1998 r., III KKN 154/97. Wkł. w Prok. i Pr. 1999, nr 5, s. 5.

37 Tak: wyrok SA w Poznaniu z dnia 13 grudnia 2012 r., II AKa 258/12, LEX nr 1307474; wyrok SA w Łodzi z dnia 21 stycznia 2014 r., II AKa 272/13, LEX nr 1425461.

38 Zob. wyrok SN z dnia 14 listopada 1972 r., V KRN 421/72, OSNKW 1973/5/61.

39 Wyrok SA w Katowicach z dnia 30 kwietnia 2015 r., II AKa 62/15, LEX nr 1745770.

40 A. SośnicKA: Przestępstwo $i$ wykroczenie przywłaszczenia $w$ polskim prawie karnym. Warszawa 2013, s. 174. 
ny), nie zaś motywacja sprawcy, popychająca go do takiego zachowania. Nie musi chodzić również o chęć zagarnięcia całego majątku wspólnego. Realizacja zamiaru powiększenia swego majątku kosztem małżonka może polegać na „wyjęciu” z majątku wspólnego tylko jednego składnika po to, by składnik ten nie stał się w przyszłości przedmiotem podziału majątku wspólnego - z pokrzywdzeniem małżonka i z jednoczesną korzyścią dla osoby, która samowolnie rzecz sprzedała ${ }^{41}$.

Wykazanie znamion strony podmiotowej przestępstwa przywłaszczenia będzie zadaniem bardzo trudnym szczególnie w sytuacji nieformalnego podziału majątku wspólnego $\mathrm{w}$ trakcie trwania wspólności majątkowej małżeńskiej. W okresie separacji faktycznej strony często dzielą się przedmiotami pozostającymi we wspólności majątkowej. Jeżeli uczyniły to w sposób ostateczny i zgodny, brak będzie podstaw do możliwości pociągnięcia małżonka do odpowiedzialności karnej, wobec braku chęci pokrzywdzenia drugiej strony i powiększenia swojego majątku kosztem przedmiotów przypadających drugiej stronie. Jeżeli natomiast propozycja podziału majątku miała nieformalny charakter, był to tylko postulat nieprzyjęty przez współmałżonka bądź nieprzyjęty ostatecznie, szczególnie gdy nie doszło jeszcze do podziału quoad usum, a więc do rozpoczęcia korzystania z rzeczy według zaproponowanego podziału, nie będzie co do zasady przeszkód do przyjęcia przestępstwa przywłaszczenia ${ }^{42}$. Sprawca postępujący z przedmiotami jak właściciel nie posiada wszakże jeszcze pewności, że podział rzeczy nastąpi zgodnie z zaproponowanym przez siebie planem, ma więc świadomość naruszania prawa własności przysługującego drugiemu małżonkowi.

Bezsporne jest, że wypełnienie kompletu znamion czynu zabronionego określonego w art. $284 \S 1$ k.k. wymaga wystąpienia skutku w postaci trwałego włączenia przedmiotu czynności wykonawczej do majątku sprawcy. Rzecz jednak w tym, że nie jest możliwy stan faktyczny, w którym sprawca mógłby skutecznie wyprowadzić daną rzecz z majątku wspólnego w taki sposób, aby w sensie finansowym wartość tego przedmiotu nie mogła podlegać podziałowi, skoro w prawie cywilnym za przedmioty objęte taką wspólnością rozumie się nie tylko rzeczy w ujęciu art. 45 k.c., ale także wszelkie wierzytelności ${ }^{43}$. Tytułem przykładu jeżeli małżonek sprzeda samochód wchodzący w skład majątku wspólnego, a otrzymane w zamian środki przekaże na własne potrzeby, drugi małżonek nie zosta-

${ }^{41}$ M. Dąbrowska-Kardas, P. Kardas. W: Kodeks karny..., s. 230; postanowienie SN z dnia 3 kwietnia 2002 r., V KKN 275/00, LEX nr 53073.

42 Postanowienie SN z dnia 03 kwietnia 2002 r., V KKN 275/00, LEX nr 53073.

43 Tak Sąd Najwyższy w uzasadnieniu uchwały z dnia 24 lipca 1997 r., III CZP 26/97, OSNC 1998/1/3, z zastrzeżeniem odnośnie do art. 33 pkt 7, oraz w uzasadnieniu uchwały z dnia 30 kwietnia 1979 r., III CZP 29/79, OSNCP1979/11/214. 
nie co do zasady pokrzywdzony finansowo, ponieważ do majątku podlegającego podziałowi, w myśl art. 45 k.r.o., wejdzie wierzytelność z tytułu sprzedaży pojazdu mechanicznego ${ }^{44}$, o ile nie są to wydatki i nakłady konieczne, poniesione na przedmioty majątkowe przynoszące dochód ${ }^{45}$ bądź na bieżące utrzymanie i zaspokojenie normalnych potrzeb jednego z małżonków ${ }^{46}$.

Powstaje więc pytanie, czy możliwe jest w okresie wspólności majątkowej małżeńskiej wypełnienie wszystkich znamion przestępstwa przywłaszczenia, w tym skutku w postaci powiększenia majątku jednego małżonka kosztem drugiego, skoro drugi z małżonków nie dozna trwałego uszczerbku w swoim majątku w tym sensie, że składnik majątkowy „wyprowadzony” przez jego małżonka zostanie „zastąpiony” przysługującą w jego miejsce wierzytelnością. W konsekwencji takiego toku rozumowania kontrowersyjna może wydawać się teza, czy rzeczywiście w wyniku takiego działania dochodzi do powiększenia majątku jednego małżonka kosztem drugiego. Wydaje się jednak, że odpowiedź na to pytanie powinna być pozytywna. Fakt, iż małżonkowi w zamian za zabraną mu rzecz przysługiwać będzie wierzytelność, nie pozbawia go przymiotu pokrzywdzenia zaborem należącego do niego przedmiotu. Poszukując analogii, można powiedzieć, że podobnie jest z kradzieżą - osobie, której zabrano należącą do niej rzecz w celu przywłaszczenia, przysługuje wierzytelność wobec sprawcy o zwrot zabranego przedmiotu bądź o zapłatę jej równowartości, a pomimo tego nie budzi wątpliwości wypełnienie kompletu znamion kradzieży. Do skutku określonego w art. 278 § 1 k.k. bądź art. $284 \S 1$ k.k. dochodzi bowiem z chwilą zaboru bądź odpowiednio przywłaszczenia rzeczy z zamiarem potraktowania jej jak swojej własności, niezależnie od ewentualnych późniejszych roszczeń przysługujących pokrzywdzonemu względem sprawcy. Te ostatnie nie niweczą bowiem dokonanego przez sprawcę zamachu na mienie pokrzywdzonego i naruszenia pozostających pod ochroną prawa karnego przysługujących mu praw.

Akceptacja stanowiska o możliwości przywłaszczenia mienia wchodzącego w skład wspólności majątkowej małżeńskiej rodzi również wątpliwości dotyczące ustalania wysokości szkody wyrządzonej przestępstwem. Art. 43 § 1 k.r.o. wprowadza jako zasadę równość udziałów małżonków

${ }^{44} \mathrm{~W}$ orzecznictwie podkreślano, że dla zastosowania art. 45 k.r.o. nie ma znaczenia, czy czynność prawna została dokonana za zgodą współmałżonka, istotne jest, że jej skutkiem było wykorzystanie na własne potrzeby środków pochodzących z majątku wspólnego (zob. uchwała SN z dnia 15 września 2004 r., III CZP 46/04, OSNC 2005/9/152; postanowienie SN z dnia 12 maja 2016 r., IV CSK 600/15, Legalis nr 1488828).

45 J. IgnaCzewski. W: Matżeńskie prawo majątkowe. Red. J. IgnaCzewsKi. Warszawa 2014, s. $150-151$.

${ }^{46}$ Por. postanowienie SN z dnia 21 marca 1977 r., III CRN 31/77, OSNCP 1977/12/243. 
w majątku wspólnym, co sugeruje ustalenie szkody na poziomie połowy wartości rzeczy. Taki pogląd przyjął Sąd Apelacyjny w Poznaniu, który $\mathrm{w}$ wyroku z dnia 13 grudnia $2012 \mathrm{r}^{47}$ wskazał, że o przywłaszczeniu mienia stanowiącego mienie wspólne można mówić wtedy, gdy jedno z nich rozporządziło mieniem większej wartości niż przypadałoby jej w następstwie podziału majątku wspólnego. Powyższa konstatacja doprowadziła wskazany Sąd do przekonania o konieczności ustalenia w toku postępowania wartości zarówno całego majątku wspólnego, jak i poszczególnych przedmiotów wchodzących w jego skład celem ustalenia, czy przywłaszczenie danej rzeczy prowadziło do powiększenia majątku sprawcy kosztem majątku współmałżonka ${ }^{48}$. Czynność taka, w ocenie składu orzekającego, powinna zostać przeprowadzona przy uwzględnieniu istniejącej dotychczas współwłasności, polegającej na wzięciu pod uwagę okoliczności, że przedmioty przywłaszczone w połowie stanowią własność sprawcy.

Przyjęcie rozwiązania zaproponowanego przez Sąd Apelacyjny w przedstawionym powyżej judykacie nie byłoby jednak słuszne. Ustrój majątkowy, w którym pozostają małżonkowie, polega na bezudziałowej wspólności łącznej, która ulega przekształceniu dopiero z chwilą ustania wspólności ustawowej - to od tego momentu małżonkowie mają równe udziały w majątku wspólnym, a udziały nieoznaczone stają się udziałami oznaczonymi, co ma znaczenie o tyle, że podział majątku na równe udziały nie zawsze będzie oznaczał jego fizyczny podział na równe części ${ }^{49}$. Dopuszczalne sposoby podziału majątku wspólnego (fizyczny podział, przyznawanie rzeczy na własność z obowiązkiem spłaty, sprzedaż licytacyjna $)^{50}$ oznaczają, że w chwili trwania wspólności majątkowej małżeńskiej nie wiadomo, który z przedmiotów przypadnie konkretnemu małżonkowi. $Z$ tego względu ustawodawca w art. 35 k.r.o. zakazał zobowiązania się do rozporządzania udziałem, który przypadnie mu w majątku wspólnym lub w poszczególnych przedmiotach należących do tego majątku w razie ustania wspólności ustawowej. Bezwzględny charakter tejże reguły wynika z ukształtowania wspólności ustawowej jako bezudziałowej wspólności łącznej, trwającej aż do chwili jej ustania ${ }^{51}$.

47 II AKa 258/12, Legalis nr 731038.

${ }^{48}$ Na podobne okoliczności zwracał uwagę SN w wyroku z dnia 14 listopada 1972 r., V KRN 421/72, OSNKW 1973/5/61. W przywołanym judykacie podkreślono, że dla rozstrzygnięcia ewentualnego przywłaszczenia przedmiotów wchodzących w skład wspólnoty majątkowej małżeńskiej istotne jest ustalenie wartości ruchomości przywłaszczonych przez sprawcę, jak i wartości całego majątku wspólnego celem ustalenia ewentualnej szkody popełnionej przestępstwem przywłaszczenia.

49 A. SośnicKa: Przestępstwo..., s. 175.

${ }^{50}$ Zob. art. 212 k.c.

51 A. SośnICKA: Przestępstwo..., s. 169; zob. też przywołane przez Autorkę orzeczenie SN z dnia 30 czerwca 1951 r., C 733/50, OSN(C) 1952/2/46. 
Z wymienionych wcześniej względów w doktrynie wskazuje się, że nie ma podstaw do odejmowania (przy ustalaniu wyrządzonej szkody) od wartości rzeczy przywłaszczonej przez jednego ze współmałżonków części przypadającej mu w przyszłości, gdyż w chwili czynu nie stanowi ona jego wyłącznej własnościs ${ }^{52}$. Pogląd ten należy podzielić, nie przychylając się do wątpliwości wysuniętych przez J.F. Marca, w ocenie którego skazanie sprawcy za przywłaszczenie telewizora należącego do mienia wspólnego nie jest racjonalne, skoro w razie podziału majątku wspólnego tenże składnik prawdopodobnie zostanie mu przyznany, prowadząc do odpowiedzialności karnej za przywłaszczenie swojego telewizora ${ }^{53}$. Rzecz jednak w tym, że w chwili przywłaszczenia tenże telewizor nie należał jeszcze do sprawcy, nie stanowił jego własności, a decydujący samowolnie o rzeczy małżonek nie ma w okresie trwania wspólności majątkowej zwykle na tyle silnych podstaw, by wiedzieć z pełnym przekonaniem, jak zostanie podzielony majątek po ustaniu ustroju wspólności majątkowej małżeńskiej. Dlatego też możliwe jest przypisanie mu przestępstwa przywłaszczenia cudzej rzeczy ruchomej ze wszelkimi tego konsekwencjami, również tymi dotyczącymi wartości zabranej rzeczy.

Przytoczone powyżej argumenty przemawiają za przyjęciem stanowiska, że de lege lata brak jest podstaw do odmawiania kryminalizacji przywłaszczeniu przez małżonka przedmiotów z majątku wspólnego. Nie stoją temu na przeszkodzie w szczególności przepisy prawa rodzinnego, w tym zasada samodzielnego zarządu. Oznacza to, że decyzja o objęciu takich zachowań zakresem stosowania prawa karnego nie narusza zarówno potrzeby harmonizacji różnych dziedzin prawa, jak i zasady ostateczności prawa karnego. Można oczywiście zastanawiać się nad celowością pociągania do odpowiedzialności karnej małżonków za przesunięcia majątkowe pomiędzy dotyczącymi ich masami majątkowymi, co częstokroć wykazuje głęboki związek z życiem prywatnym i osobistym. Wydaje się jednak, że chęć powiększenia własnego majątku kosztem majątku współmałżonka, a więc osoby najbliższej, do której powinno się mieć zaufanie, cechuje się szczególną karygodnością i brak jest podstaw, by odmawiać takim sytuacjom karnoprawnej ochrony.

52 A. Sośnicka: Przestępstwo..., s. 175-176; zob. też R.A. STEFańsKi: Odpowiedzialność karna za zabór mienia stanowiącego wspólność majątkową. Prok. i Pr. 1995, nr 10, s. 122.

53 J.F. MARZEC: $Z$ problematyki zaboru przez jednego z matżonków mienia objętego wspólnościq ustawowa. PiP 1959, nr 11, s. 853. 


\section{Bibliografia}

\section{Literatura}

Dąbrowska-Kardas M., Kardas P. W: Kodeks karny. Część szczególna. T. III: Komentarz do art. 278-363. Red. A. Zoll. Warszawa 2016.

DudzIK M.: Glosa do postanowienia Sądu Najwyższego z dnia 28 marca 2012 r., I KZP 1/12. IN 2013, nr 3.

GaŁązKa M.: Przywłaszczenie na szkodę wspótwłaściciela w świetle polskiego prawa karnego. PiP 2013, nr 11.

GOŁĘBIOWSKI K.: Zarząd majątkiem wspólnym matżonków. Warszawa 2012.

GóRNIOK O.: Znaczenie subsydiarności prawa karnego w jego interpretacji. PiP 2007, nr 5.

IgNACZEwsKi J. W: Matżeńskie prawo majątkowe. Red. J. IgnACZEWsKI. Warszawa 2014.

IgNACZEWSKI J.: Kodeks rodzinny i opiekuńczy. Komentarz. Warszawa 2010.

MARZEC J.F.: Z problematyki zaboru przez jednego z matżonków mienia objętego wspólnościa ustawowa. PiP 1959, nr 11.

Mróz T.: Zgoda małżonka na dokonanie czynności prawnej $w$ ustroju majątkowej wspólności ustawowej. Warszawa 2011.

PietrzyKowski K. W: Kodeks rodzinny i opiekuńczy. Komentarz. Red. K. PietrzyKowsKi. Warszawa 2015.

RzonCa S.K.: Pojęcie zarządu majątkiem wspólnym matżonków. Warszawa 1982.

SKowrońsKa-Bocian E. W: Kodeks rodzinny i opiekuńczy. Komentarz. Red. J. WiERCIŃSKI. Warszawa 2014.

SokоŁowski T. W: Kodeks rodzinny i opiekuńczy. Red. H. Dolecki, T. SoкоŁowski. Warszawa 2013.

SośNICKA A.: Przestępstwo i wykroczenie przywłaszczenia w polskim prawie karnym. Warszawa 2013.

STEFAŃSKI R.A.: Odpowiedzialność karna za zabór mienia stanowiącego wspólność majątkowa. Prok. i Pr. 1995, nr 10.

Sychowicz M. W: Kodeks rodzinny i opiekuńczy. Komentarz. Red. K. PIASECKI. Warszawa 2011.

Sychowicz M.: Uwagio zakresie zarządu majątkiem wspólnym matżonków. W: Ksiega jubileuszowa Profesora Tadeusza Smyczyńskiego. Red. A. AndrZEJEwsKI, L. KociUcKi, M. ŁączKowsKa, A.N. Schulz. Torun 2008.

SylwestrZAK A. W: Zarząd majątkiem wspólnym. Komentarz. Red. M. BALWICKA-SzCZYRBA, Warszawa 2016.

ŻóŁteк S.: Prawo karne gospodarcze $w$ aspekcie zasady subsydiarności. Warszawa 2009.

\section{Orzecznictwo}

Orzeczenie SN z dnia 30 czerwca 1951 r., C 733/50. OSN(C) 1952/2/46.

Uchwała SN z dnia 30 maja 1979 r., III CZP 29/79. OSNCP 1979/11/214.

Uchwała SN z dnia 24 lipca 1997 r., III CZP 26/97. OSNC 1998/1/3.

Uchwała SN z dnia 15 września 2004 r., III CZP 46/04. OSNC 2005/9/152. 
Wyrok SN z dnia 14 listopada 1972 r., V KRN 421/72. OSNKW 1973/5/61.

Wyrok SN z dnia 24 listopada 1998 r., III KKN 154/97. Wkł. w Prok. i Pr. 1999, nr 5, s. 5 .

Postanowienie SN z dnia 21 marca 1977 r., III CRN 31/77. OSNCP 1977/12/243.

Postanowienie SN z dnia 13 marca 1981 r., III CRN 35/81. OSNC 1981/11/220.

Postanowienie SN z dnia 17 kwietnia 2000 r., V CKN 25/00. LEX nr 1129169.

Postanowienie SN z dnia 3 kwietnia 2002 r., V KKN 275/00. LEX nr 53073.

Postanowienie SN z dnia 29 sierpnia 2007 r., I KZP 18/07. OSNKW 2007/9/64.

Postanowienie SN z dnia 12 maja 2016 r., IV CSK 600/15. Legalis nr 1488828.

Wyrok SA w Poznaniu z dnia 13 grudnia 2012 r., II AKa 258/12. Legalis nr 731038.

Wyrok SA w Warszawie z dnia 30 października 2013 r., II AKa 322/13. LEX nr 1392064.

Wyrok SA w Łodzi z dnia 21 stycznia 2014r., II AKa 272/13. LEX nr 1425461.

Wyrok SA w Katowicach z dnia 30 kwietnia 2015 r., II AKa 62/15. LEX nr 1745770. 